\title{
Physiological Concepts with Inbuilt Mathematics in Scratches on Ishango Bone by Upper Paleolithic People of Africa
}

\author{
Dr. Swapan Kumar Adhikari, Ph.D. (Sc) \\ Retired Headmaster, GHUSURI UCHCHA MADHYAMIK VIDYALAYA
}

\begin{abstract}
It was as early as 35000 BCE, bones and stones were the open pages for writing anything that mind had to say. It was women who were the torch bearers. They scratched on any surface available to them and poured their mind upside down. It is now the wise men of the posterity to decipher the pristine symbols. We have collected a few items from different sources and applied our mind to decode the primitive dots and lines of those sleeping alphabets of an age much earlier than the hieroglyphic days of the known civilisation where involvement of mathematics has been explored.
\end{abstract}

We said 'open sesame' and the door of unexplored mathematics, astronomy and religion etc.: opened up in front of our eyes! Here is our presentation.

Keywords:- Ishango-Bone, Paleolithic period, Belgian Congo, Physiological concept.

\section{INTRODUCTION}

On search of origins of Homo sapiens ${ }^{l}$, our previous records reveal that our universe is nearly as old as about 13.7 billion years whereas our Earth is about 4.5 billion years old and consequently eukaryotic ${ }^{2}$ life is about 3 billion years old. The emergence of primates occurred sometime about 65 million years ago. Fossil record indicates that Hominins including ancestors of humans lives only onetenth of the time. Our ancestors lived harsh and short lives as they were prey of larger African species. As per study of fossils of various hominins species in Africa by anthropologists and paleo-archaeologists that most striking features of these fossils had been characterised by osseous lesions, fractures and dental imprints of predators and scavengers where fossils are located in the lairs of predators such as lions which suggested that many of our ancestors lived brief and difficult lives struggling with neighbouring predators.

Homo sapiens and their ancestral species evolved in Africa because first bipedalism had been clearly evident in

\footnotetext{
${ }^{1}$ are the only extant members of the subtribe human (the great apes, Hominids).

${ }^{2}$ organisms whose cells have a nucleus enclosed within membranes.
}

australopithecines ${ }^{3}$ from the foot prints in the volcanic ash in Laetoli, Tanzania. Considering somewhat archaic ancestors, Australopithecus Africanus ${ }^{4}$, and modern African natives the debate over the place of human origins, first raised by Darwin $^{5}$ in the 19th century where he suggested that Africa was the continent of origin. He also resurfaced in a debate over the place, not merely of early hominid but also anatomically modern humans.

Our ancestral started their survival and sharp turning for their improvement from Paleolithic era ${ }^{6}$.

On the people of Ishango, the discoverer Jean de Heinzelin ${ }^{7}$ expressed as: “.... Some of the molars we found were as large as those of Australopithecus, the pre-human 'man-ape'. Moreover, the Neanderthal skulls .... On the other hand, Ishango-mandid not have the overhanging brow of Neanderthal and other earlier forms ... his chin was shaped like the chin of modern man .... The long bones of the body were quite slender ... this add up to a unique picture. No other fossil-man shows such a combination ... Primitive and Neanderthaloid in part, Ishango-man was nevertheless a true Homo sapiens ...." ${ }^{\text {. }}$.

\footnotetext{
${ }^{3}$ Australopithecines, generally Australopithecus genus apparently evolved in Eastern Africa around 4 million years ago and eventually extinct two million years ago.

${ }^{4}$ This species lived, between 3 and 2 million years ago, in a dry forest with open spaces.

${ }^{5}$ Charles Robert Darwin (12 February 1809 - 19 April, 1882) was an English naturalist, geologist and biologist. He was best known for his contributions to science evolution. He established that all species of life have descended over time from common ancestors.

${ }^{6}$ The Paleolithic dates from 2.6 million years ago and ended around 15,000 BCE with the Mesolithic or Epipaleolithic (period from 20,000 BCE to 10,500 BCE) in Western Europe and with the Epipaleolithic in warmer climates such as Africa. The Paleolithic age began when hominids (early human) started to use stones as tools for bashing, cutting and scraping.

${ }^{7}$ Jean de Heinzelin de Braucourt (6 August 1920 - 4 November 1998) was a Belgian geologist who worked mainly in Africa. He worked at the universities of Ghent and Brussels. He gained international fame in 1960 when he discovered the Ishango Bone.

${ }^{8}$ Jean de Heinzelin: "Ishango", Scientific American, Volume.206 (June, 1962), p.113.
} 
"Ishango-man was .... A true Homo sapiens possibly Negroid ${ }^{9}$ who represented the emergence in Africa of an indigenous Nego population from the older Paleolithic stock ...." ${ }^{\prime \prime}$.

Heinzelin also claimed that: "Besides primitive tools Ishango-man ${ }^{11}$ also left large number of grinding and pounding stones .... To pound seeds and grain for food and these argue for relatively advanced stage of culture ... On the whole their cultural habits seen comparable to those contemporaries in Europe" 12 .

On the structure of excavated bone the excavator said: "The most fascinating and suggestive of all the artifacts at Ishango is not a harpoon point but a bone tool handle with a small fragment of quartz still fixed .... At his head .... It may have been used for engraving tattooing or even for writing of some kind. Even more interesting, however, are its markings: groups of notches arranged in three distinct columns. The pattern of these notches leads me to suspect that they represent more than pure decoration"'13.

Eminent American Anthropologist as well as Paleolithic Archeologist Alexander Marshak seconded the above statement as: "The anatomically modern human at Ishango were different than those in the Ice-Age at Europe and the climate, ecology and culture were different as well. But the human capacities were clearly comparable. I had assumed that the Ishango notation indicated changing seasonal behaviour and movements of humans and animals. The excavation at Ishango and at neighbouring 'Ishangian' sites document the presence of complex, mixed ecology that included lakeside ${ }^{14}$, savanna and a use of other seasonal resources such as crabs, snails, tortoises, ostrich eggs, small and large mammals and a probable gathering of seasonal seeds, fruits and root"'15.

Prehistoric artefacts are silent by nature, but these put us in mystery for finding its reach demonstartion. So, we possess an intention to make them talk and this attitude

${ }^{9}$ It is known to be de Heinzelin Conjecture. Conjecture or hypothesis indicates an educated guess raised by profound intuition.

${ }^{10}$ Alexander Marshack: The Root of Civilization, Moyer Bell Limited, Mount Kisco, New York, 1991; p.22.

${ }^{11}$ The man who lived in the shore of Lake Edward, archaeologists called them Ishango, stood at sort of halfway point in the development of modern man and civilisation. They lasted a few hundred years then one day was buried in volcanic ash.

${ }^{12}$ Jean de Heinzelin: "Ishango", Scientific American, Volume.206 (June, 1962), p.106.

${ }^{13}$ Jean de Heinzelin: "Ishango", Scientific American, Volume.206 (June, 1962), p.109-110.

${ }^{14}$ Lake Edward: High in the Eastern mountains of central equatorial Africa surrounded by steep hills. Head water sources from the Nile. It is fair-sized lake, some 50 miles long and 30 miles wide.

${ }^{15}$ Alexander Marshack: The Root of Civilization, Moyer Bell Limited, Mount Kisco, New York, 1991; p.32. appears very rigorous to make them spaek truth. Particularly mathematical truths are difficult to express as artefacts lie in fictionalised anachronisms. It appears camouflaged to express its mathematical truths. Mathematics has definite truths and any marking can be expressed in mathematical language.

Perhaps due to various tantalising hypothesis on marks although it is simple but crucial fact about Ishango bone has been occasionally overlooked.

The lines (scratches) appeared to vary in length of course having a definite regularity. These marks maintain concept binary numbers and it appears mysterious to us. Ishango people's mathematics may be their 'religion'.

Upper paleolithic ${ }^{16}$ people started to keep records on bones, soft-stones and bas-reliefs. Their signs were not easy to read but their counting had started by marking. Archeologists had given explanation in different ways and we are expressing their physiological views. Over 100 Paleolithic statuettes of women having similar physical attributes have been found in Europe. These are as early as $35000 \mathrm{BCE}$ and as late as $10000 \mathrm{BCE}$. These were earliest prehistoric arts. Afterwards we find scratches on bones were apparently intentionally made and these were not tooth marks by either man or animal. These were read by archeologists as count of lunar periods but we read these as physiological phenomena of women. These scratches were deep which indicate these were done by prehistoric women. Prehistoric women were basically home-makers. They wanted to express and keep records of whatever they observed. The style of putting Scratches on flat surface or collecting pellets as memoir or count fingers / digit-sections for record of an event was probably forerunner of hieroglyphic inscriptions. Counting or mathematics was probably initiated by women in this way: discussed in later sides. The language was rudimentary mathematical. Deciphering these codes need play of imagination.

${ }^{16}$ Upper Paleolithic (Late Stone age) is the third and last subdivision of the Paleolithic i.e. Old Stone Age. Its dates were between 50,000 $\mathrm{BCE}$ and 10,000 BCE which is beginning of Holocene i.e. recent and it is the age of behavioural modernity before the advent of agriculture. It was indicative of ceremony, ritual and dance. These early modern men's subcultures had been could be subdivided into three classes according to their tools style as: (a) Perigordian between 35,000 BCE and 20,000 BCE; (b) Aurignacian (Appeared in Eastern Europe around 43,000 BCE and in Western Europe between 40,000 BCE and 36,000 BCE) and (c) Gravettian (between 33,000 BCE and 22,000 BCE). This difference was also taken into account by their skeletal differences. Anatomically, modern human (Homo sapiens) are believed to have emerged around 2,00,000 BCE, although their lifestyle changed very little from that Archaic humans of Middle Paleolithic until $50,000 \mathrm{BCE}$, when there was a marked increase in the diversity of artifacts. This period coincides with the early human migration throughout Eurasia, which contributed to the extinct of the Neanderthals. 
Archeologists tell in their way. Our perception support events relating to female physiology.

\section{DISCUSSION}

According to d'Errico et al. 2012 [Ref.8] recent archaeological discoveries have revealed that beads, engravings and bone tools were already present in southern Africa 75,000 years ago. Many of these artifacts disappeared by 60,000 years ago due to massive supereruption of the Toba volcano in Sumatra, led an enormous ash cloud and volcanic winter, had reduced the polpulation of humans significantly. It was that modern behaviour appeared in the past and was subsequently lost before firmly established. In this period paleo-archaeological evidences suggest that humans took refuge in coastal regions during these difficult times because coast was comparatively reach in food sources. One of such place was Ishango.

Most archeologists think that $\operatorname{San}^{17}$ hunter-gatherers' cultural adoptation emerged on or before 20,000 BCE. They marked on fibula of baboon, nearly cylindrical bone, into three columns of etching marking clearly into set of groups with usage of duodecimal number system. Reanalysing of organic artifacts from South Africa shows that inhabitants of the cave in the early later Stone-age used notched bones for notional purposes.

\footnotetext{
${ }^{17}$ The San people, also known as Bushman, are members of various Khoisan speaking indigenous hunter-gatherer people of South Africa, whose territories span at Botswana, Namibia, Angola, Zambia, Zimbabwe, Lesotho and South Africa. The ancestors of hunter-gatherer San people are considered to be first inhabitants of what is now Botswana and South Africa. In this area, stone tools and rock art paintings date back over 70,000 years and are by far the oldest known art. A set of tools almost identical to that used by the modern San and dating to 44,000 BCE was discovered at Border Cave in Kwazulu-Natal in 2012. The San tribe, one of the most intriguing people in this world, are the region's earliest inhabitants (it is estimated that they have been living here for last 30,000 + years) and are still settled in many parts of Southern Africa. The San people are the first people of Africa. This means the Sans are descendants of the first who ever lived here, before black or white people migrated into African region. Archaeologists, geneticists agree that the San are the descendants of the original Homo Sapiens groupings, who occupied Southern Africa, for at least 150,000 years. According to genetic studies and the geneticists: That one of the oldest gene patterns found in some modern humans, is that of the KhoeSan, and it dates back around 800,000 years.
}

Those people peoples had chosen baboon's bone as they thought baboon as their Kemetic God, Djehuty ${ }^{18}$.

The Ishango bone is a bone-tool in Upper Paleolithic Era. It is a dark brown fibula of baboon. The scratches were intentionally made and these were tooth marks either by man or beast. We demonstrate ir as following ways:

Initially, it was thought to be a tally stick, as it has a series of tally marks carved in three columns running along the length of the tool.

$>$ It has also been suggested that the scratches might have been created for better grip or for some other nonmathematical reason.

$>$ The marking also may be the product of New Stone Age to express existence of homo-sapiens.

$>$ Ishango bone might serve as a sort of stone-age-pencil as there is an attachment of a sharp piece of quartz $z^{19}$ sticking out at the upper end of it.

$>$ Bone used, between their fingers, to mark on other objects by the quartz.

$>$ The bone may also has many new speculations about hunter-gatherers.

$>$ Notches have may have been marked to form a patterntool on some logical reasoning.

$>$ It may be recognised as Paleolithic slide-rule in contrast with arithmetical game or calendar explanation.

$>$ It is a primitive Mathematical-tool.

$>$ The bone indicates some African populations reproducing prehistoric numerals.

\footnotetext{
${ }^{18}$ Kemetic God - Djehuty was usually associated with Moon, Mathematics, Writing and Science. Use of baboonbones as mathematical devices has been continuous throughout Africa suggesting Africans always held the baboon as sacred and associated with the Moon, Mathematics and Time.

${ }^{19}$ The banks of Lake Edward also provided Ishangoans with lots of cut quartz material. This rock is present in a very hard translucent to pearly white crystal form. The quartz was used as the primary material for tool-making, cutting or scraping.
} 

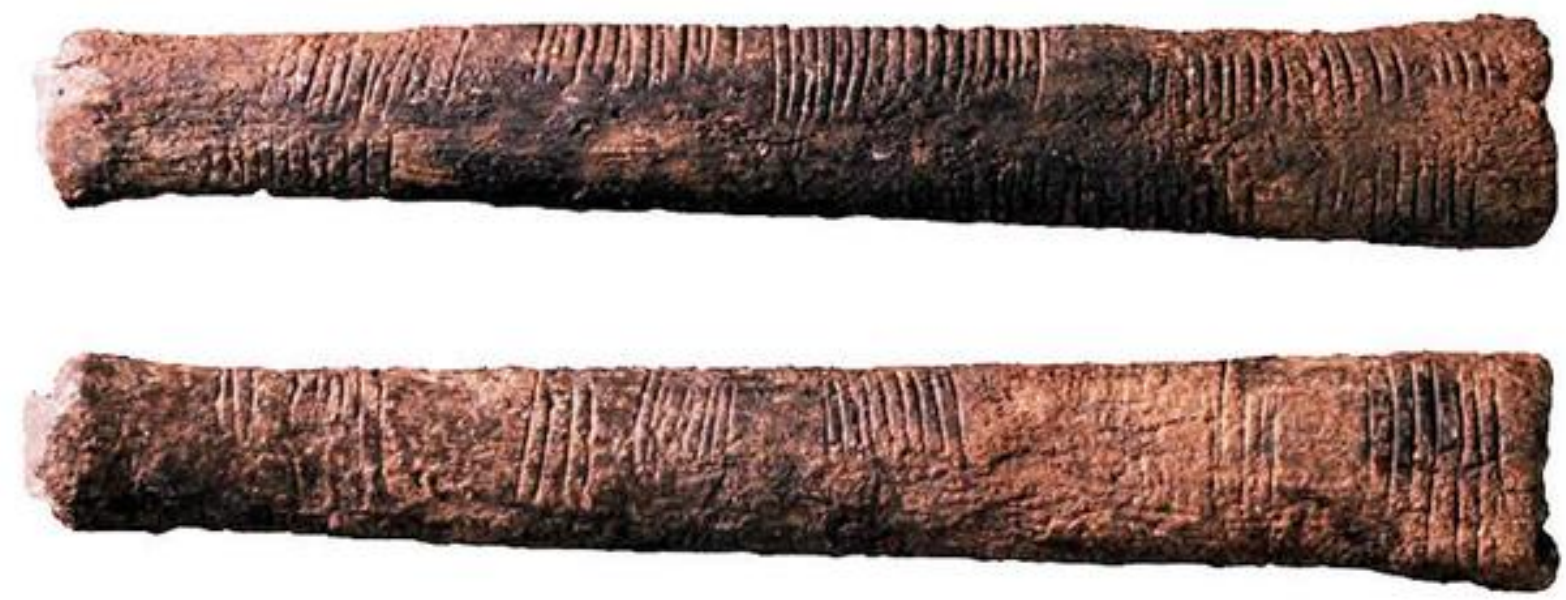

Fig 1:- Demonstration-I: Ishango Bone

Bone served some kind of numeric reference table for the person holding it, as they, in turn, detailed the quality of items or events into the side of some other bone.

$>$ The bone served a real, yet abstract, purpose.

$>$ This bone scratches indicates physiological events in life of primitive women.

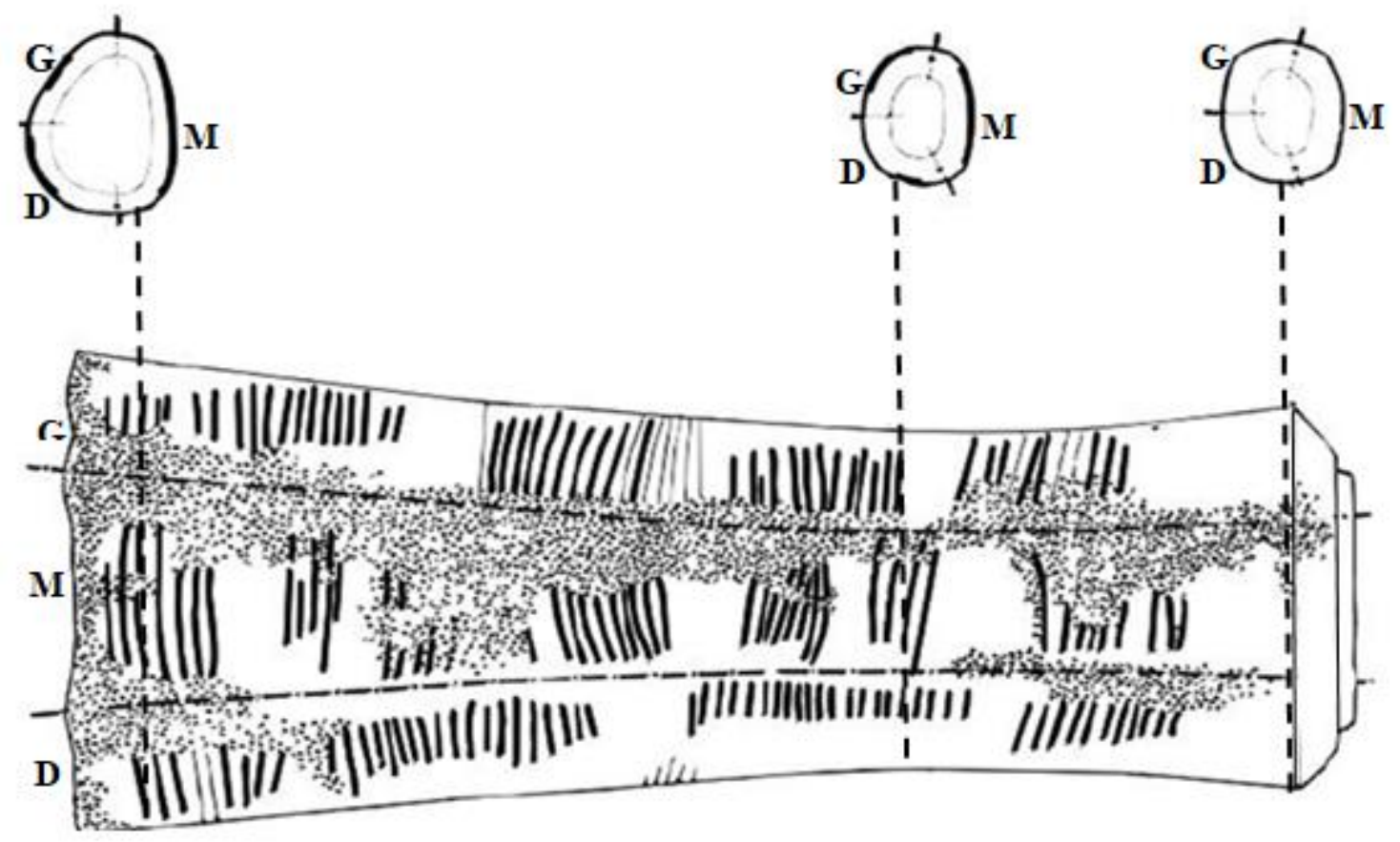

Fig 2:- Demonstration-II: Structural Presentation of Scratches on Ishango Bone

The Ishango bone ${ }^{20}$ was found in 1960 by Belgian Professor Jean de Heinzelin de Braucourt in Congo. Excavation was possible because Congo was colony of Belgium ${ }^{21}$ then.

\footnotetext{
${ }^{20}$ The site was discovered in 1935 by Hubert Damas (27 September 1910 - 19 April 1964), a zoologist from Liège University, during one of several scientific research trips. Damas came across the remains of ancient human activity: human bones and bone harpoon heads. Damas did not explore it further, as it was not his subject of research, but mentioned his discovery in a publication, stating that the area could be the target of a later in-depth expedition. Afterwards this was carried out by Jean de Heinzelin during archaeological excavations that took place in 1950 and 1959.

${ }^{21}$ The Belgian Congo was a Belgian colony (15, November 1908 - 30 June 1960) in Central Africa and got independence in 1960. The present-day name is Democratic Republic of the Congo (DRC), in 1964.
} 
It was discovered in the area of Ishango ${ }^{22}$ near South Semliki River ${ }^{23}$. The bone was found among the remains of a small community gathered in this area of Africa. The settlement had been burried out from a volcanic eruption.

The age of artifact was first estimated between 9,000 BCE and 6,500 BCE. However, the dating of the site was re-evaluated with the help of antropologists and now it has been accepted universally that to be more than 20,000 years old.

The Ishango bone is on permanent exihibition at the Royal Belgium Institute of Natural Sciences, Brussels, Belgium and it has given remembrance by vertical lines on Postage Stampon the occasion of World Mathematical Year 2000.

Bone carries total of 168 notches distributed in three columns along the length whereas these are nearly parallel within each group but different length and orientation.

On physiological view point we express as:

We may consider G-column as:Life history of a woman in megalithic era in years where each scratch mark is indicative of a year.

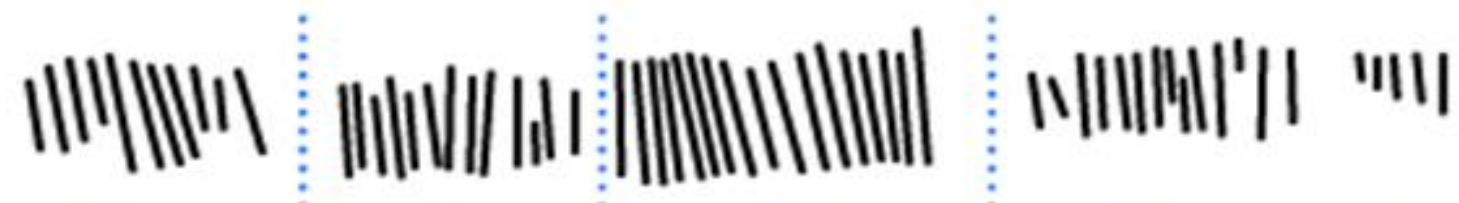 \\ 11 \\ 13 \\ 17 \\ 14 \\ $5=60$}

Fig 3

* From left:

- 11 scratch-marks indicate physiological changes among the females after 11 years i.e. indicative of menarche.

- Gap indicates new episode of tale.

- $13+17$ years scratch-marks indicate of life showing fertile years of life showing menstruating Thus she reached the age of menopause at 41 years. The small gap after 13 may indicate her physiological disability for some dis-ease.

- Further 19 scratches indicate life after menopause: a healthy old age which probably interrupted for short period. This takes her calculation of years to $60+$ making room for gap of years or more after $14^{\text {th }}$ geriatric years.

- Life years of this unknown lady probably ended in mid of 60s of longivity or it may be some incidence in her life which discontinued her record on bone.

$\checkmark$ We may consider D-column as: Events o life in months i.e. sexual episodes in month where each line is indicative of a month.

\footnotetext{
${ }^{22}$ It is fisherman-village at the furthest source of Nile on the border of Congo and Uganda. The prehistoric inhabitants used the abundant resources on the banks of Lake Edward year-round. They, were nomads, did not have to travel long distances to find food and they followed animal migrations. The Ishangoans, like all hunter-gatherer populations, really understood their environment; they only exploited a small area. Amongst the remains, excavators found numerous fish bones, as well as those of mammals such as hippopotamus, warthog, otter, buffalo, and several species of antelope. Equally there were the remains of birds such as ibis, pelican and spoonbill. These bones show signs of having been cut up, indicating that these animals were eaten. The abundant resources help to assume that the Ishangoans had a sedentary lifestyle based around the lake. It is sub-station of Virunga National Park, situated on the Northern shore of Lake Edward, as the lake formerly held the biggest hippo population in the world. ${ }^{23}$ Semliki River (Also known as Semuliki) is a major river, 140 kilometres (87 miles) long, in the Democratic Republic of Congo (DRC) and Uganda in Central and East Africa. It flows north from Lake Edward to Lake Albert in the Albertine Riff west of the Rwenzori Mountains. It forms part of the international border between the DRC and the western Ugandan near the Semuliki National Park.
} 


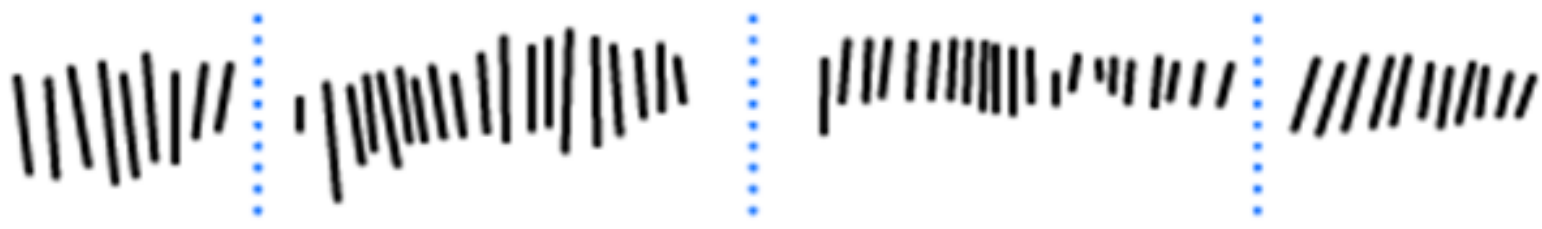 \\ 9 \\ 19 \\ 21 \\ 11}

Fig 4

* From left:

- Gap after 9-scratch marks indicate First pregnancy after 9 months of menarche.

- Gap after 19-scratch marks indicate lactating phase: sucking baby after delivery.

- Next gap indicative of next episode.

- Then 21-scratch marks indicate next pregnancy after 21 months (ended in post maturity).

- Next 11-scratch marks indicate 11-lunar months of a post-matured pregnancy.

- Further records are not available here.

We may consider M-column as: Events o life in days i.e. life episode in days where menstrual flow and the incidental matter (each line is indicative of a day).

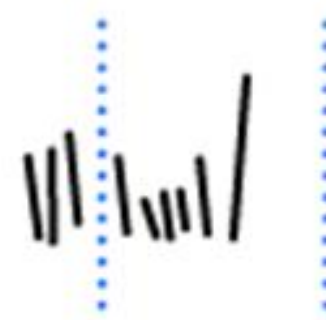

3

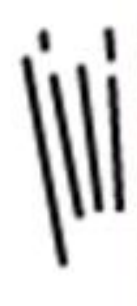

4

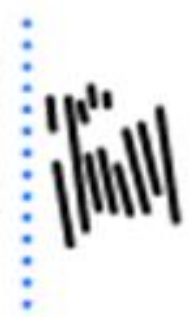

8

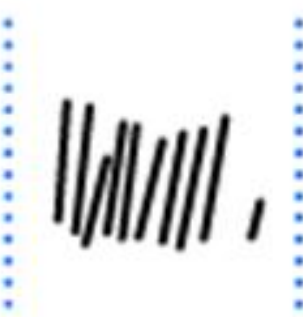

$9+1=10$

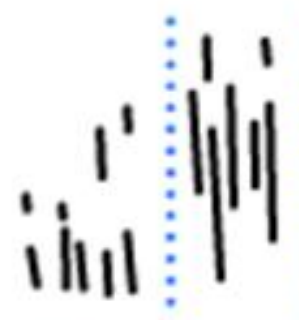

5

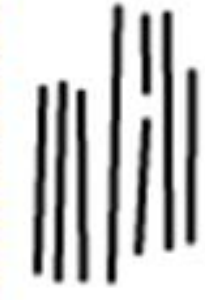

7

Fig 5

* From left:

- Gap after 3-scratches is indicative of 3-days pain before menarche.

- Out of 6-scratches, 3-small scratches: Feeble flow for 3-days then 3-fountain scratches indicate profuse flow for 3-days.

- Long gap: Rẹtu-Snān: a social custom of approaching the male partner after thorough cleaning \& freshness.

- Next 4-scratches may be for arranging suitable chance for: Intercourse with suitable male after 4-dates (dating).

- Thereafter 8-scratches: Intercourse with pleasure for 8-days.

- Then after a few days.

- A gap after 9+1=10-scratches: Intercourse with high pleasure for 9-days but 10th day was not pleasurable for bodily changes or some personal reason or premenstrual pain.

- 5-Fountain scratches: Menstrual period of 5-days.

- Next 5 irregular scratches indicate Rtu Snān and dating gap i.e. after 5-days intercourse with full vigour for 7consecutive days.
We think in that period two things were main criteria to those people, of them one was and other was huntinggathering for their food. Therefore, it may be plea that women of that period had expressed the physiological conditions scrating on soft stones and bones as the had no very sharp weapons then. Even to establish our argument we are presenting some engraving on bone of that era.

Human and animal birth were great mysteries of Upper Paleolithic man. Following Venus figures are reflecting the biological miracle of birth.

Among the artefacts many Venus figurines were found in upper Paleolithic period. According to archeological literatures these were from Aurignacian to Megdalenian $^{24}$. These are exaggerated female characteristics with large breasts, thigs and buttocks which is relevant to child birth.

\footnotetext{
${ }^{24}$ The Magdalenian refers to one of the later Archeological culture of the Upper Paleolithic in Western Europe, dating from around 17,000 to12,000 years ago.
} 
This is a ceramic statuette of nude female figure, dated 29000 BCE - 25000 BCE, found in Moravian Basin, south of Brno, Germany; indicate pregnancy by enlarged (1) breasts; (2) abdomen; (3) buttock; (4) thigh.
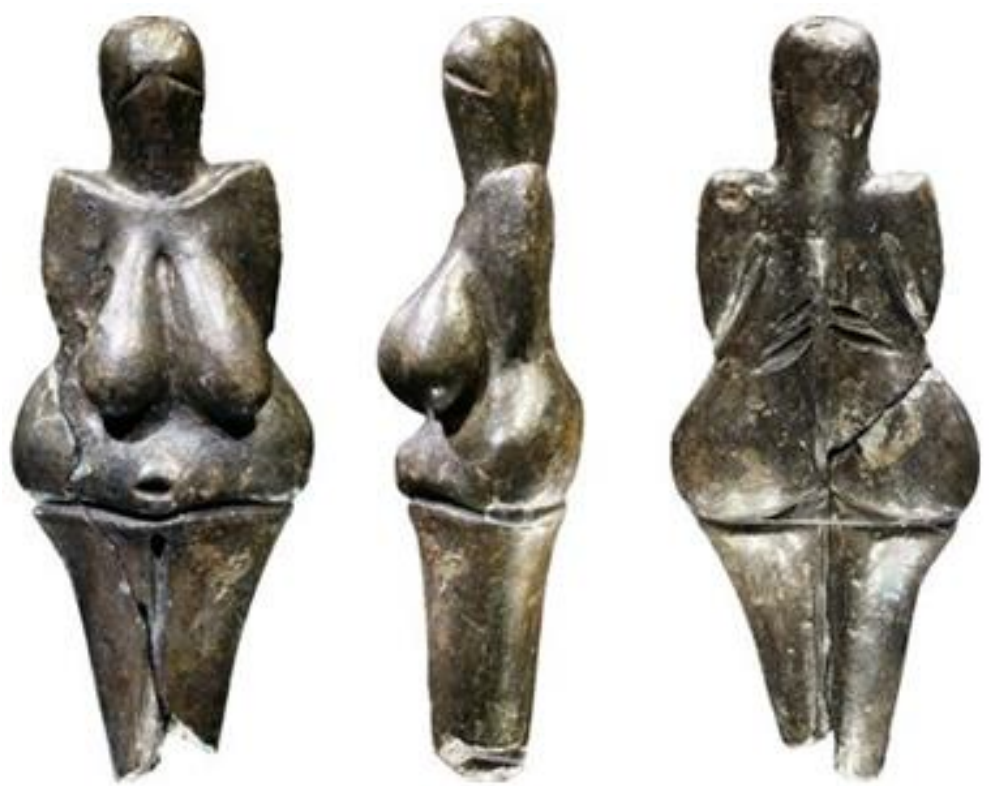

Fig 6:- Demonstration-III: Woman from Dolni Věstonice of Czech Republic of 2600 BCE

This is pregnant woman figure from Willendrof, Austria of size 4.75 inches made of lime-stone painted with ochre of Paleolithic period between 22000 BCE \& 21000 BCE by the courtesy of Naturhistorisches Museum, Vienna. From left: (a) Front-view; (b) Side-view.

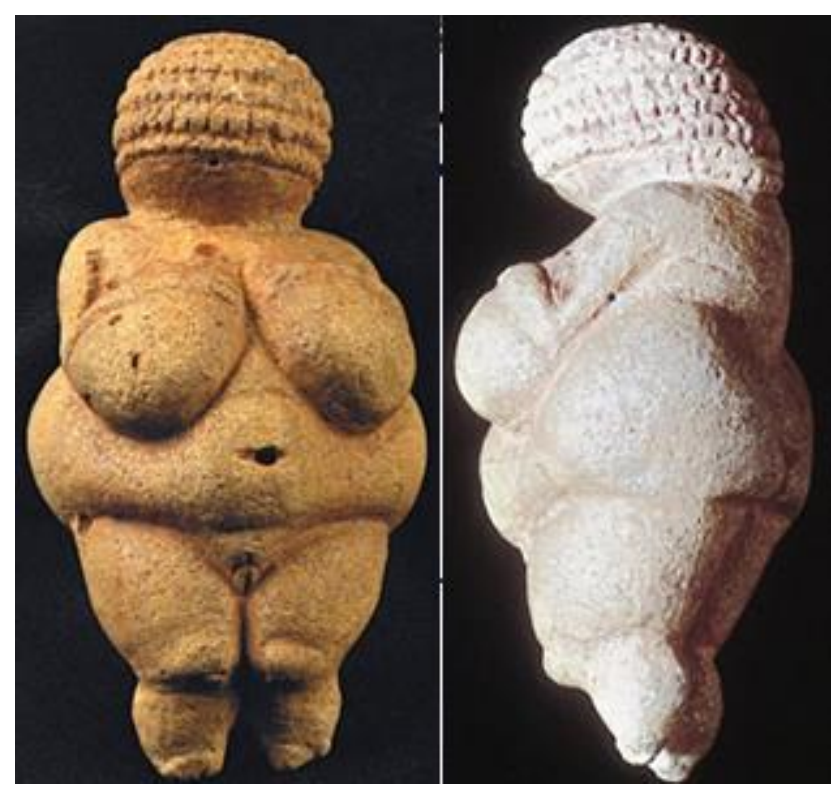

Fig 7:- Demonstration-IV: Venus of Willendrof

This is bass-relief (incised or sunken i.e. engraved relief) of a nude woman from Laussel, Dorogne, France within period of $25000 \mathrm{BCE}$ to $23000 \mathrm{BCE}$ made of Limestone. She is holding a bison horn where crescent inscribed with 13scratches and its origin is Musée d'Aquitaine à Bordeaux i.e. in the museum of Aquitaine collection from documents from history of Bordeaux.

Right-hand hold a crescent with 13-scratch marks whereas left hand has 4 scratch marks and hidden thumb.

- Existing Archæo-astronomical concept is: (a)13th month in a year in lunar 4-years interval; (b) Half lunation period is 13days i.e. from full-moon to new-moon and vice-versa. 
* Our physiological concept is:

- There will be 13-menstrual period in a leap-year.

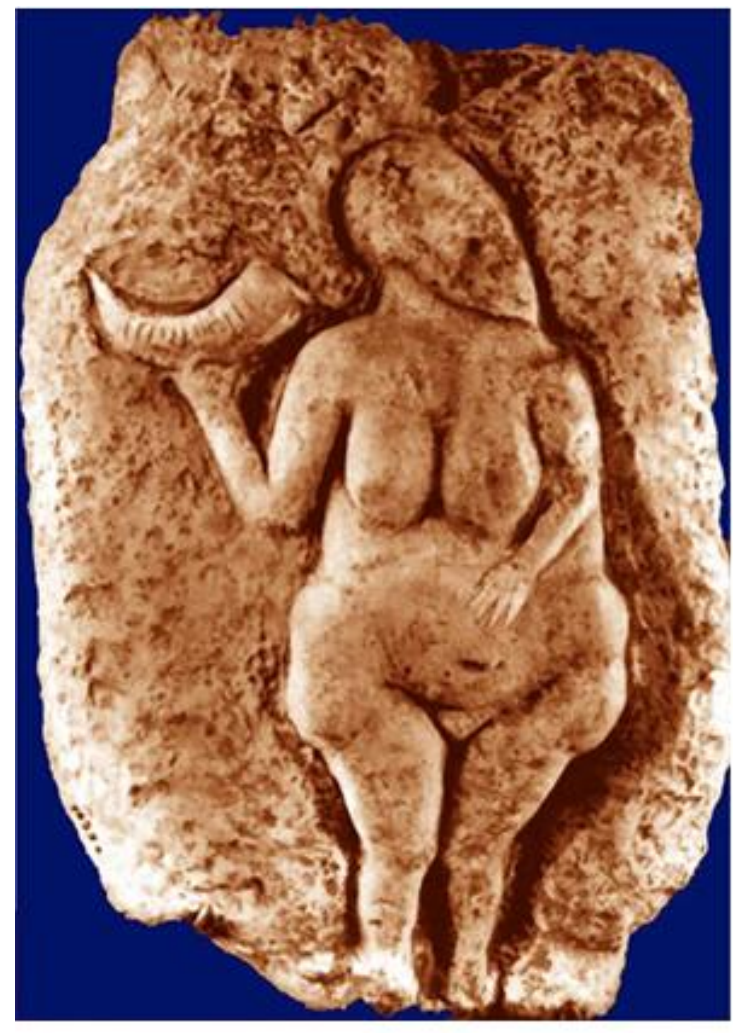

Fig 8:- Demonstration-V: Venus of Laussel

Demonstration-VI: Different bas relief within $30000 \mathrm{BCE}$ to $25000 \mathrm{BCE}$

It is fromMuseum für Vor-und Frühgeschichte i.e. Berlin Museum of Prehistory and Early History, Germany.

* Relaxation or Approaching a male for mating or ready for mating: She is supporting her right-hand just before intercourse.

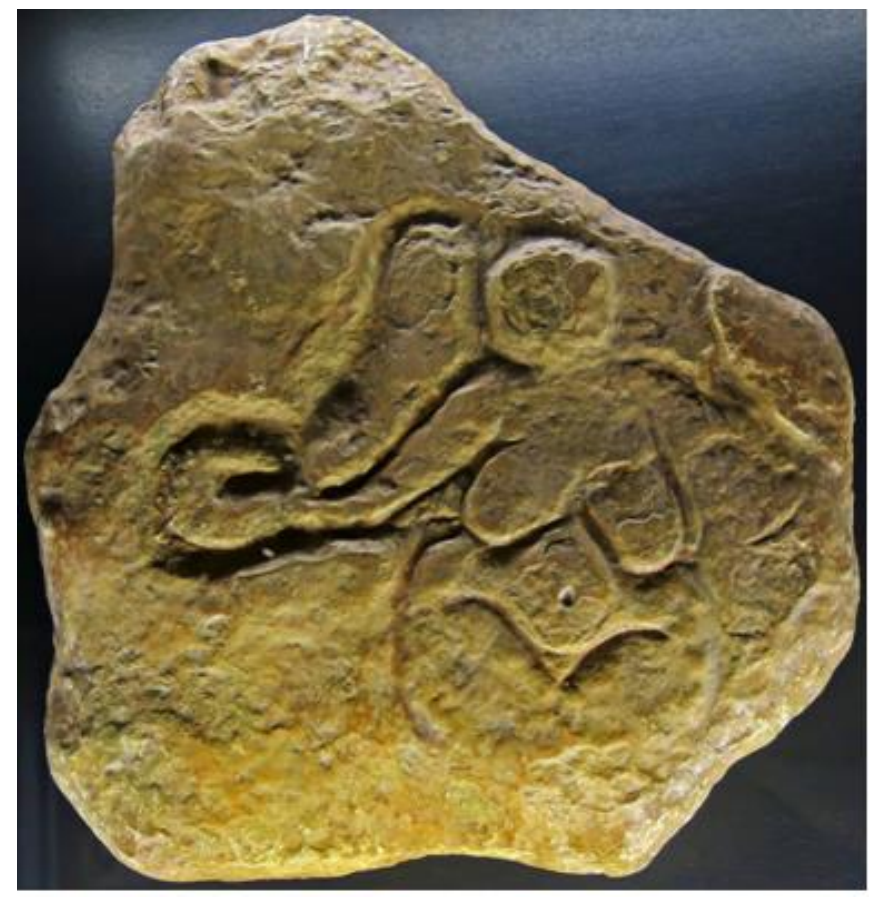

Fig 9:- Demonstration-VIA: Berlin Venus 
It is from Laussel, France, made of Sand-stone from Musée d'Aquitaine ä Bordeaux.

* Agility or She is in pleasure of mating. Legs are omitted and vuva is showing.

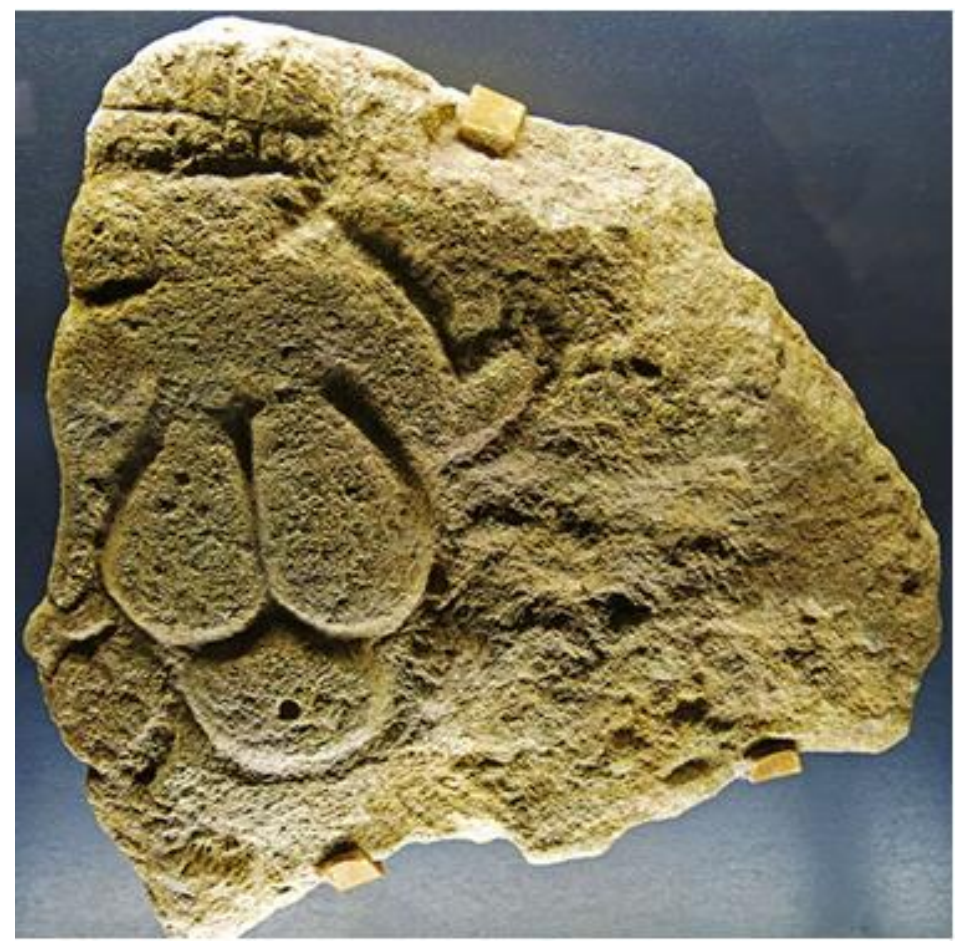

Fig 10:- Demonstration-VIB: Femme à la tête quadrillée

It is from Laussel, France, made of Sand-stone from Musée d'Aquitaine ä Bordeaux.

* Yogic Posture or She is in great pleasure and holding legs up by hands at the time of intercourse.

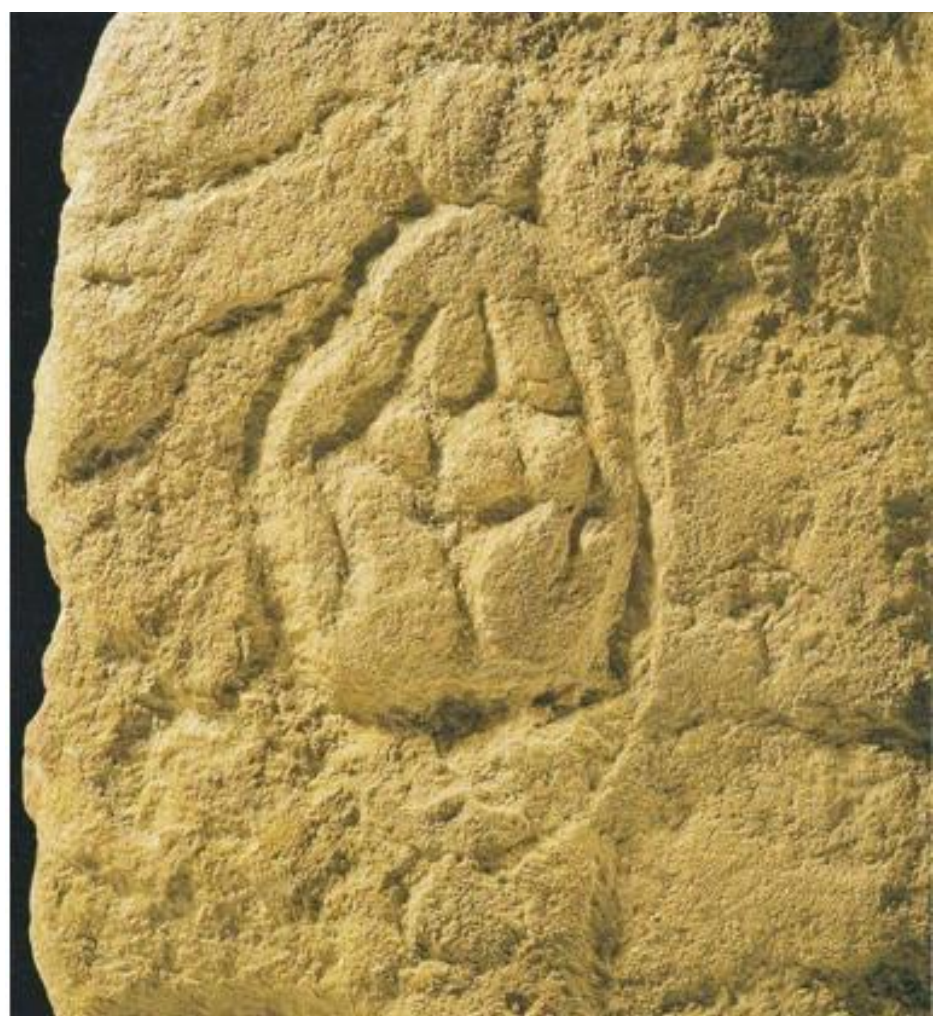

Fig 11:- Demonstration-VIC: The Paying Card Venus 
It is from Laussel, France, made of Sand-stone from Musée d'Aquitaine ä Bordeaux.

Period: Aurignacian ${ }^{25}$

* Engraved Vulva on Lime-Stone.

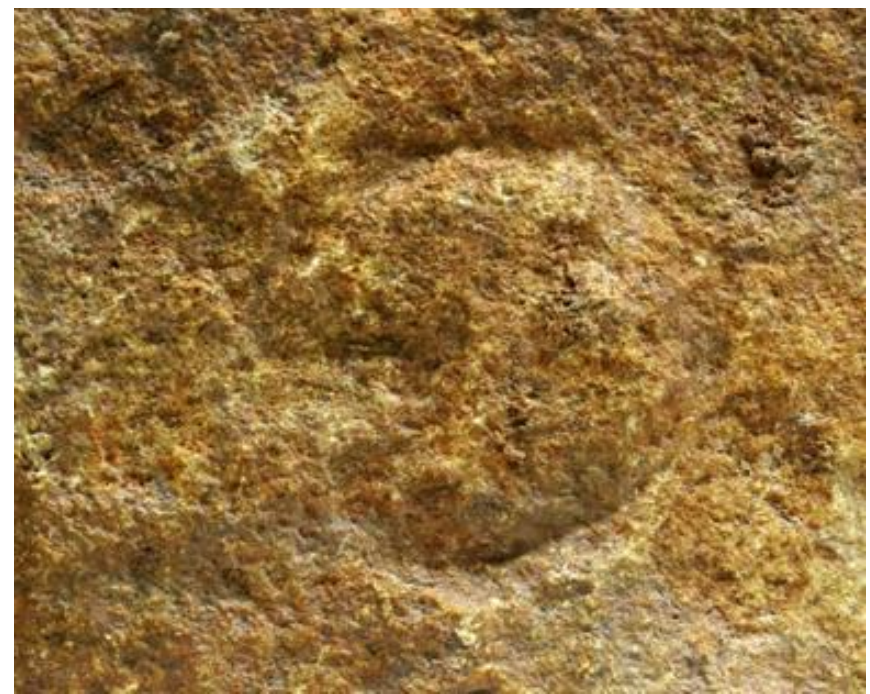

Fig 12:- Demonstration-VID: Engraved Vulva

It is from Laussel, France, made of Lime-stone from Musée d'Aquitaine ä Bordeaux.

Period: Gravettian ${ }^{26}$

Engraved Penis on Lime-Stone.

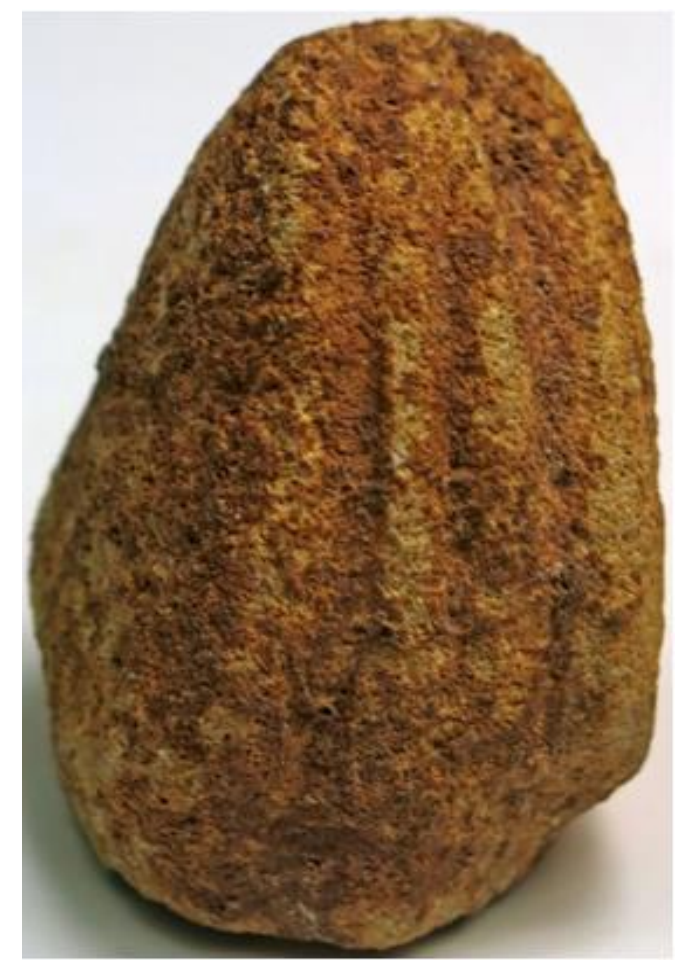

Fig 13:- Demonstration-VIE: Glans Penis

\footnotetext{
${ }^{25}$ An Early Aurignacian or Proto-Aurignacian stage is dated between about 40,000 BCE and 35,000 BCE. The Aurignacian proper lasts from about 35,000 BCE to 30,000 BCE.

${ }^{26}$ Succeeded Aurignacian after 33,000 BCE and lasts to 22,0000 BCE.
} 


\section{It is from Laussel, France, made of Sand-stone from Musée d'Aquitaine ä Bordeaux.}

\section{Intimacy Or Male \& Female - one having intercourse with female from back.}

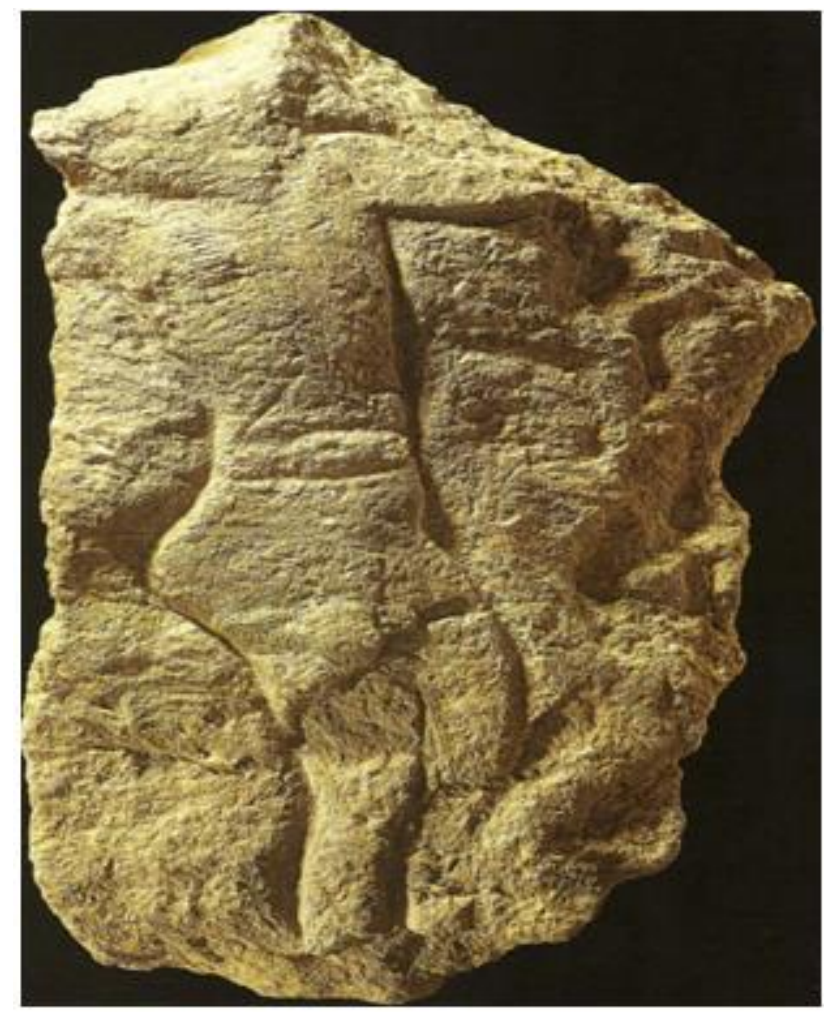

Fig 14:- Demonstration-VIF: The Human Torso

\section{RESULT}

In that period hunter-gatherers usually intended to performance of collecting food and sex that is why we have expressed their physiological relation.

\section{CONCLUSION}

The Ishango site still has not revealed all of its secrets; the Semliki Valley still hides other prehistoric sites. This region of Africa has been inhabited by Homo sapiens sapiens for at least 1,00,000 years. We still lack a lot of information to truly understand the ancient Ishangoans' lifestyle, settlement and way of thinking. Therefore, sooner or later, archaeologists must return to the banks of Lake Edward to complete the puzzle that was started in the fifties. No doubt, the missing pieces are still hidden.

Discoverer wrote: Scratches on the Ishango-Bone may represent an arithmetical game of some sort, devised by a people who had a number system based on 10 as well as a knowledge of duplication and prime numbers ${ }^{27}$. The mathematicians looked into Jean de Heinzelin's ideas about number notation, and came to the conclusion that the bone was a kind of sliding scale which involved variations of the three and four base numbers, and by extension of base number twelve $(3 \times 4)$. However, they concluded that there

${ }^{27}$ Jean de Heinzelin: "Ishango", Scientific American, Volume.206 (June, 1962), p.111. was not enough proof to confirm an understanding of prime numbers. Alexander Marshack, a Harvard archaeologist, also believes it is a system of number notation, but one which is related to the lunar calendar. Olivier Keller, another mathematician, cautions against the temptation to project our modern culture of viewing numbers everywhere onto the bone. In his opinion, it is a habit that prevents the viewer from noticing other forms of symbols, those which are present in a range of media (on bones, stones and cave art) from the Upper Paleolithic era which also deserve a thorough investigation.

According to archeologist, particularly Alexander Marshak, the marks were of lunar observations in the Ishango culture i.e. series of notches matches the number of days contained in successive phases of the moon.

One of American Ethnomathematicians Claudia Zaslavsky ${ }^{28}$ concluded that: "Creator of the Ishango was in fact a woman who used bone to track her menstrual cycle".

The bone suggests that African population of the eponymous place on Lake Edward had produced prehistoric numerals more than 20,000 years ago.

${ }^{28}$ Claudia Zaslavsky (12 January, 1917 - 13 January, 2006) was an American Educator and Ethnomathematician. She advanced the study of links between mathematics and world cultures, especially with her pioneering book Africa Counts. 
So-called prehistoric "notched sticks" made from bone, ivory or antler are not rare, they have been found around the world. The notches are generally thought to be marks representing counting by pairing, the mark could symbolize an object, a day or a person; the invention of numbers was not necessary as they could count by associating a mark with an entity (like those above). The use of this kind of stick continues among those who have not learned to count. Until recently, in Europe shepherds who could not count used counting sticks to calculate the number of sheep in their flocks. They made a mark for every animal taken to pasture, and then had to gather as many sheep as there was marks. This very simple tool is well-known and there is a whole range of similar ancient items.

Most of the archeologists confirmed that scratches are of lunar calendars. But they cannot ignore the concept of menstrual cycle and physiological events of women.

Therefore, we may say: African women kept track of their cycle by lunar calendars. They were undoubtedly the first mathematician.

At the end I am intended to express the Ishango-bone discoverer's conclusion: “.... this knowledge .... may have spread northward. The first example of a well-worked out mathematical table dates from the dynastic period in Egypt. There are some clues, however, that suggest the existence of cruder systems in prehistoric times. Because the Egyptian number system was a basis and a perquisite for the scientific achievements of classical Greece, and thus for many of the developments in science that followed, it is even possible that the modern world owes one of the greatest debts to the people who lived in Ishango. Whether or not this is the case, it is remarkable that the oldest clue to the use of a number system by man dates back to the central Africa of the Mesolithic period. No excavation in Europe have turned up such a hint" ${ }^{\prime 2}$.

\section{REFERENCES}

[1]. Atkinson., Richard John Copland: Stonehenge; London, 1956.

[2]. Brooks., A. S. and Smith., C. C.: Ishango Revisited: New Age Determinations and Cultural Interpretation; The African Archeological Review, Volume.5, pp.6578.

[3]. Brown., Peter Lancaster: Megaliths, Myths and Men (An Introduction to Astro-Archeology); Dover Publications, Inc., Mineola, New York, USA, 1976.

[4]. Darling., David: The Universal Book of Mathematics; John Wiley \& Sons, Inc., 2004

[5]. d'Errico., Francesco; Backwell., Lucinda; Villa., Paolo; Degano., Ilaria; Lucejko., Jeannette J.; Bamford., Marion K.; Higham., Thomas F. G.; Colombini., Maria Perla and Beaumont., Peter B.: Early Evidence of San Material Culture Represented by Organic Artefacts from Border Cave, South Africa; Proceedings of National Archeological Science; August, 109(33), pp.13214-13219.

[6]. d'ERRICO, 2009.

[7]. d'Errico., Francesco and Watts., Ian: Engraved Ochres from the Middle Stone Age Levels of Blombos Cave, South Africa; Journal of Human Evolution, Number.57, pp.27-47.

[8]. Everett., Caleb: Numbers and the Making of Us Counting and the Course of Human Cultures; Harvard University Press, Massachusetts, 2017.

[9]. Heinzelin., Jean de: Ishango; Scientific American, Volume.206, Issue.6, June, pp.105-116.

[10]. Ifran., Georges: The Universal History of Numbers from Prehistory to the Invention of the Computers; John Wiley \& Sons, Inc., 2000.

[11]. Joseph., George Gheverghese: The Crest of the Peacock (Non-European Roots of Mathematics); Third Edition; Princeton University Press, Princeton, Oxford, 1991.

[12]. Keller., Olivier: The Fables of Ishango, or the Irresistible Temptation of Mathematical Fiction; Agrégé in Mathematics, PhD, EHESS.Lockyer., Sir Joseph Norman: The Dawn of Astronomy (A Study of Temple Worship and Mythology of the Ancient Egyptians); Dover Publications, Inc., Mineola, New York, USA, 1964.

[13]. Mankiewicz., Richard: The Story of Mathematics; Princeton University Press, Princeton, New Jersey, 2000.

[14]. Marshak., Alexander: The Female Image: A Time Factored Symbol - A Study in Style and Modes of Image use in European Upper Paleolithic; Proceedings of the Pre-Historic Society, Volume.57(1), pp.17-31.

[15]. Marshak., Alexander: EA Reply to Davidson on Mania: Early Pre-Upper Paleolithic ProblemSolving; Rock Art Research, Volume.8(1), pp.47-48.

[16]. Marshak., Alexander: Evolution of Human Capacity; Year Book of Physical Anthropology, pp.1-34.

[17]. Marshak., Alexander: The Root of Civilisation; London, 1972.

[18]. Pletser., Vladimir: Does the Ishango Bone Indicate Knowledge of the Base 12? An Interpretation of Prehistoric Discovery, the First Mathematical Tool of Humankind; European Space Research and Technology centre, European Space Agency, P.O. Box 2200 Noordwijk, The Netherlands, 2012

[19]. Thom., Alexander: Megalithic Lunar Observatories; Oxford, UK, 1971.

[20]. Wilson., Paul Hastings: The Ishango Bone; A Blue Atlas Press Book, New York, USA, 2012.

[21]. Rudman., Peter S.: How Mathematics Happened The First 50,000 years; Prometheus Book, USA, 2006.

${ }^{29}$ Jean de Heinzelin: "Ishango", Scientific American, Volume.206 (June, 1962), p.114, 116. 